\begin{tabular}{|c|l|}
\hline Title & Conversion of glycerol into allyl al cohol over potassium-supported zirconia iron oxide catalyst \\
\hline Author(s) & Konaka, Aya; Tago, Teruoki; Y oshikawa, Takuya; Nakamura, A yaka; Masuda, Takao \\
\hline Citation & $\begin{array}{c}\text { A pplied catalysis b-environmental, 146, 267-273 } \\
\text { https://doi.org/L0.1016/.apcatb.2013.03.007 }\end{array}$ \\
\hline Issue Date & 201403 \\
\hline Doc URL & http://hdl.handle.net/2115/54715 \\
\hline Type & article(author version) \\
\hline File Information & Manuscript_Glycerol to A llyl A Icohol .pdf \\
\hline
\end{tabular}

Instructions for use 


\section{Conversion of Glycerol into Allyl Alcohol over Potassium-Supported Zirconia-Iron Oxide}

\section{Catalyst}

Aya Konaka, Teruoki Tago*, Takuya Yoshikawa, Ayaka Nakamura, and Takao Masuda

Research Group of Chemical Engineering, Division of Chemical Process Engineering, Faculty

$$
\text { of Engineering, Hokkaido University, }
$$

N13W8, Kita-ku, Sapporo, Hokkaido, Japan 060-8628

* Corresponding author should be addressed

E-mail:tago@eng.hokudai.ac.jp

Tel: $+81-11-706-6551$

Fax: $+81-11-706-6552$ 


\section{Abstract}

The catalytic conversion of glycerol was performed with iron oxide-based catalysts for production of allyl alcohol using a fixed-bed flow reactor at $623 \mathrm{~K}$ under atmospheric pressure. The glycerol dehydration proceeds on acid sites of catalysts while the allyl alcohol production is assumed to be catalyzed by non-acidic sites of catalysts through a hydrogen transfer mechanism. Different alkali metals, including $\mathrm{Na}, \mathrm{K}, \mathrm{Rb}$, and $\mathrm{Cs}$ were supported on $\mathrm{ZrO}_{2}-\mathrm{FeO}_{\mathrm{X}}$ and all of them gave impressively higher allyl alcohol yield and suppressed glycerol dehydration due to the reduced catalyst acidic property. $\mathrm{K}$-supported $\mathrm{ZrO}_{2}-\mathrm{FeO}_{\mathrm{X}}\left(\mathrm{K} / \mathrm{ZrO}_{2}-\mathrm{FeO}_{\mathrm{X}}\right)$ was chosen for further studies, and allyl alcohol yield remarkably increased up to $27 \mathrm{~mol} \%-\mathrm{C}$ at the $\mathrm{K}$ content of 3-5 mol\%. Since no external hydrogen gas is supplied to the system, the hydrogen transfer mechanism should take place between the reaction of glycerol and either hydrogen atoms derived from formic acid forming during the reaction, or active hydrogen species produced from the decomposition of $\mathrm{H}_{2} \mathrm{O}$ by $\mathrm{ZrO}_{2}$.

Addition of $\mathrm{Al}_{2} \mathrm{O}_{3}$ to $\mathrm{K} / \mathrm{ZrO}_{2}-\mathrm{FeO}_{\mathrm{X}}\left(\mathrm{K} / \mathrm{Al}_{2} \mathrm{O}_{3}-\mathrm{ZrO}_{2}-\mathrm{FeO}_{\mathrm{X}}\right)$ was examined in order to improve structure stability during the glycerol conversion. $\quad \mathrm{Al}_{2} \mathrm{O}_{3}$ addition to the catalyst was effective to achieve higher structure stability, leading to high glycerol conversion with stable allyl alcohol yield of above $25 \mathrm{~mol} \%$-C. Moreover, $\mathrm{K} / \mathrm{Al}_{2} \mathrm{O}_{3}-\mathrm{ZrO}_{2}-\mathrm{FeO}_{\mathrm{X}}$ can be applicable to the conversion of crude glycerol which is the waste solution obtained from biodiesel production. 


\section{Keywords}

Biomass utilization; Glycerol conversion; Crude glycerol; Iron oxide catalyst; Allyl alcohol 


\section{Introduction}

Biodiesel, one of renewable and alternative fuels to fossil fuels, appears to be significant fuel due to depletion of fossil fuels and global warming problem [1-3]. Glycerol is produced as a main by-product in a biodiesel production which is a transesterification of triglycerides, such as vegetable oils and animal fats, and methanol [4,5]. Therefore, development of an effective utilization for glycerol is highly desired.

Conversion of glycerol into useful chemicals is widely studied [6-16]. Most of the works report on converting glycerol into acrolein [6-8], acetol [9], or 1,2- and 1,3-propanediol [10-12]. Acrolein and acetol are produced through gas-phase dehydration of glycerol over acidic catalysts including $\mathrm{Nb}_{2} \mathrm{O}_{5}$, heteropolyacids, and zeolites, and copper metal catalysts, respectively. 1,2- and 1,3-propanediol are obtained through hydrogenolysis of glycerol over supported $\mathrm{Ru}, \mathrm{Rh}$, and Pt catalysts. Additionally, some of the works have reported recently on synthesis of allyl alcohol from glycerol which is assumed to form via hydride or hydrogen transfer mechanism [13-16]. Among these chemicals, allyl alcohol can be more useful and valuable chemical because it can be used as an important chemical intermediate in the production of resins, paints, coatings, silane coupling agents, and polymer crosslinking agents, etc. Thus, allyl alcohol is one attractive and valuable chemical that can be obtained from glycerol. 
On the contrary, we have developed zirconia-iron oxide catalyst, $\mathrm{ZrO}_{2}-\mathrm{FeO}$, for the catalytic conversion of biomass resources. We have succeeded in producing phenol and ketones from tar derived from wood biomass [17-20], sewage sludge [21], and fermentation residue [22] over $\mathrm{ZrO}_{2}-\mathrm{FeO}_{\mathrm{X}}$, in which $\mathrm{ZrO}_{2}$ loaded on $\mathrm{FeO}_{\mathrm{X}}$ contributes to the high catalytic 5 performance and stability. Since $\mathrm{ZrO}_{2}-\mathrm{FeO}_{\mathrm{X}}$ works effectively on the organic compounds having hydroxyl and carboxyl groups, the catalyst is expected to be applicable to the catalytic conversion of glycerol into useful chemicals.

Using $\mathrm{ZrO}_{2}-\mathrm{FeO}_{\mathrm{X}}$, we have succeeded in producing useful chemicals, including propylene, allyl alcohol, carboxylic acids, and ketones, from reagent glycerol [23]. These useful chemicals are expected to be produced from glycerol through two main pathways: one pathway involves the production of allyl alcohol and propylene (Pathway I), and another involves the production of carboxylic acids from acetol, followed by their ketonization (Pathway II), as shown in Fig. 1. We previously reported that the incorporation of $\mathrm{ZrO}_{2}$ into $\mathrm{FeO}_{\mathrm{X}}$ significantly improved the BET surface area of the catalysts; $\mathrm{FeO}_{\mathrm{X}}$ has the surface area of 14

$15 \mathrm{~m}^{2} \mathrm{~g}^{-1}$ while $\mathrm{ZrO}_{2}-\mathrm{FeO}_{\mathrm{X}}$ with $\mathrm{ZrO}_{2}$ content of $7.0 \mathrm{wt} \%$ has that of $56 \mathrm{~m}^{2} \mathrm{~g}^{-1}$ [23,24]. This increase in the catalyst surface area further improved the catalytic activity for the production of the useful chemicals shown in Fig. 1. Furthermore, it was also revealed that $\mathrm{ZrO}_{2}-\mathrm{FeO}_{\mathrm{X}}$ improved the catalytic stability because $\mathrm{ZrO}_{2}$ has an ability to produce active oxygen species 
from $\mathrm{H}_{2} \mathrm{O}$ for regeneration of the consumed lattice oxygen in $\mathrm{FeO}_{\mathrm{X}}$ [23-25]. In our previous research, $\mathrm{ZrO}_{2}-\mathrm{FeO}_{\mathrm{X}}$ was considered to have acid sites which generally promote dehydration reaction [26-28]. In order to obtain higher selectivity to the Pathway I, particularly allyl alcohol, suppressing the Pathway II and the acrolein production, which are the dehydration of glycerol, appears to be a solution to our system.

In this study, different alkali metals, including $\mathrm{Na}, \mathrm{K}, \mathrm{Rb}$, and $\mathrm{Cs}$ were supported on $\mathrm{ZrO}_{2}-\mathrm{FeO}_{\mathrm{X}}$ to suppress glycerol dehydration that proceeded on the acid sites of the catalyst. $\mathrm{Na}$-, $\mathrm{K}-, \mathrm{Rb}$-, and Cs-supported $\mathrm{ZrO}_{2}-\mathrm{FeO}_{\mathrm{X}}$ were used for the catalytic conversion of glycerol. $\mathrm{K}$-supported $\mathrm{ZrO}_{2}-\mathrm{FeO}_{\mathrm{X}}$ was selected for the further studies and its effects of $\mathrm{K}$ content on the product yield and catalytic stability were investigated. Main objectives of this study are to investigate the effects of supported alkali metals on the product yield and to develop a catalyst showing high selectivity to allyl alcohol with high stability. Finally, the catalyst was applied to convert crude glycerol derived from biodiesel production to allyl alcohol.

\section{Experimental}

\subsection{Catalyst preparation and characterization}

All reagents were purchased from Wako Pure Chemical Industries (Japan). $\mathrm{ZrO}_{2}-\mathrm{FeO}_{\mathrm{X}}$ was prepared by a coprecipitation method using $\mathrm{Fe}\left(\mathrm{NO}_{3}\right)_{3} \cdot 9 \mathrm{H}_{2} \mathrm{O}$ and $\mathrm{ZrO}\left(\mathrm{NO}_{3}\right)_{2} \cdot 2 \mathrm{H}_{2} \mathrm{O}$ 
aqueous solutions and ammonia solution. $10 \mathrm{wt} \%$ ammonia solution was added by a micropump to the aqueous solution of $\mathrm{Fe}\left(\mathrm{NO}_{3}\right)_{3} \cdot 9 \mathrm{H}_{2} \mathrm{O}$ and $\mathrm{ZrO}\left(\mathrm{NO}_{3}\right)_{2} \cdot 2 \mathrm{H}_{2} \mathrm{O}$ under continuous stirring until the $\mathrm{pH}$ of each solutions reached $\mathrm{pH} 7$ and filtered subsequently. The obtained precipitate was dried at $383 \mathrm{~K}$ for $24 \mathrm{~h}$ to obtain $\mathrm{ZrO}_{2}-\mathrm{FeO}_{\mathrm{X}}$ precursor. In our 5 previous research [23], the effect of $\mathrm{ZrO}_{2}$ content on product yield from glycerol was examined, in which it was revealed that $\mathrm{ZrO}_{2}$ content of $7.0 \mathrm{wt} \%$ in $\mathrm{FeO}_{\mathrm{x}}$ was appropriate. In this study, $\mathrm{ZrO}_{2}-\mathrm{FeO}_{\mathrm{X}}$ with $\mathrm{ZrO}_{2}$ content of $7.0 \mathrm{wt} \%$ was used as a catalyst.

The $\mathrm{ZrO}_{2}-\mathrm{FeO}_{\mathrm{X}}$ precursor was used to prepare alkali metal-supported $\mathrm{ZrO}_{2}-\mathrm{FeO}_{\mathrm{X}}$ by an impregnation method with their content of 1.0 mol\% based on the total amount of $\mathrm{Zr}$ and $\mathrm{Fe}$.

10 As for $\mathrm{K}$, its content was varied in the range of $0-10 \mathrm{~mol} \%$, denoted hereafter "K[Z]/ZrO $2-\mathrm{FeO}_{\mathrm{X}}$ " where $\mathrm{Z}$ was the $\mathrm{K}$ content (mol\%). Aqueous solution of each alkali metal nitrates was added to the $\mathrm{ZrO}_{2}-\mathrm{FeO}_{\mathrm{X}}$ precursor, stirred and dried in a vacuum at $313 \mathrm{~K}$ for $2 \mathrm{~h}$ and $333 \mathrm{~K}$ for $2 \mathrm{~h}$. The obtained precipitate was again dried at $383 \mathrm{~K}$ for $24 \mathrm{~h}$ and finally calcined at $773 \mathrm{~K}$ for $2 \mathrm{~h}$ in an air atmosphere. The BET surface area of the representative catalyst, $\mathrm{K}[5] / \mathrm{ZrO}_{2}-\mathrm{FeO}_{\mathrm{X}}$, was $51 \mathrm{~m}^{2} \mathrm{~g}^{-1}$ and its crystal phase was hematite.

$\mathrm{K}$-supported $\mathrm{Al}_{2} \mathrm{O}_{3}-\mathrm{ZrO}_{2}-\mathrm{FeO}_{\mathrm{X}}, \mathrm{K} / \mathrm{Al}_{2} \mathrm{O}_{3}-\mathrm{ZrO}_{2}-\mathrm{FeO}_{\mathrm{X}}$, was also prepared by a combination of coprecipitation and impregnation methods. $\mathrm{Al}_{2} \mathrm{O}_{3}-\mathrm{ZrO}_{2}-\mathrm{FeO}$ x precursor was first obtained by a coprecipitation method similarly to the protocols for the preparation of $\mathrm{ZrO}_{2}-\mathrm{FeO}_{\mathrm{X}}$ [24]. 
$\mathrm{Al}\left(\mathrm{NO}_{3}\right)_{3} \cdot 9 \mathrm{H}_{2} \mathrm{O}$ was used as the $\mathrm{Al}_{2} \mathrm{O}_{3}$ source. $\mathrm{Al}_{2} \mathrm{O}_{3}$ content was $10 \mathrm{~mol} \%$ of the total amount of $\mathrm{Al}, \mathrm{Zr}$, and $\mathrm{Fe}$. $\mathrm{K}$ was supported on $\mathrm{Al}_{2} \mathrm{O}_{3}-\mathrm{ZrO}_{2}-\mathrm{FeO}$ by an impregnation method. The $\mathrm{Al}_{2} \mathrm{O}_{3}-\mathrm{ZrO}_{2}-\mathrm{FeO}_{\mathrm{X}}$ precursor and $\mathrm{KNO}_{3}$ aqueous solution were mixed, stirred, and subsequently dried in a vacuum at $313 \mathrm{~K}$ for $2 \mathrm{~h}$ and $333 \mathrm{~K}$ for $2 \mathrm{~h}$. The obtained precipitate was dried at $383 \mathrm{~K}$ for $24 \mathrm{~h}$ and finally calcined at $973 \mathrm{~K}$ for $2 \mathrm{~h}$ in an air atmosphere. The obtained catalyst had the BET surface area of $62 \mathrm{~m}^{2} \mathrm{~g}^{-1}$ and the crystal phase of hematite.

The composition of the catalysts and the amount of $\mathrm{ZrO}_{2}$ or alkali metals in the catalysts were confirmed by X-ray fluorescence analyzer (XRF Supermini; Rigaku Co. Ltd.). The surface areas of the catalysts were measured by a nitrogen adsorption and desorption method (Belsorp mini; BEL Japan, Inc.). The crystal phases of the catalysts were analyzed by an X-ray diffractometer (JDX-8020; JEOL). The acidic property of the catalysts was evaluated by the temperature-programmed desorption profile of ammonia ( $\left.\mathrm{NH}_{3}-\mathrm{TPD}\right)$ method using the quadropole mass spectrometer (BEL-mass; BEL Japan, Inc.) combined with the catalyst analyzer (BEL-cat; BEL Japan, Inc.). The sample was pretreated in Ar flow at $823 \mathrm{~K} . \quad$ After cooling down to $373 \mathrm{~K}, \mathrm{NH}_{3}$ was introduced for $30 \mathrm{~min}$ and the sample was subsequently heated at $10 \mathrm{~K} \mathrm{~min}^{-1}$ in Ar flow up to $823 \mathrm{~K}$.

\subsection{Catalytic conversion of glycerol}


The catalytic conversion of glycerol over different catalysts was carried out in a fixed-bed flow reactor for 2-6 $\mathrm{h}$ at the reaction temperature of $623 \mathrm{~K}$ under atmospheric pressure. Catalysts were pelletized and formulated into the particle size of 300-850 $\mu \mathrm{m}$. Nitrogen gas was introduced as a carrier gas at the flow rate of $20 \mathrm{~cm}^{3} / \mathrm{min}$. The values of $W / F$, where $W$ is

5 the amount of catalyst $(\mathrm{g})$ and $F$ is the flow rate of the feedstock $\left(\mathrm{g} \mathrm{h}^{-1}\right)$, were varied in the range of $1-5 \mathrm{~h}$ to obtain similar initial glycerol conversion between each experiment. Glycerol aqueous solution was used as a feedstock and fed to the reactor with a syringe pump. Crude glycerol solution, the waste solution obtained in the process of biodiesel fuel production, was also used as a feedstock. The main source of the crude glycerol is edible vegetable oil and methanol. Potassium hydroxide, $\mathrm{KOH}$, is used as a catalyst for the transesterification reaction of them to produce biodiesel fuel and glycerol.

The liquid and the gas products were collected with an ice trap and a gas pack, respectively, for every $2 \mathrm{~h}$ and product yields showed the average of each $2 \mathrm{~h}$. The liquid products were analyzed by a gas chromatograph equipped with a flame ionization detector

15 (GC-2014; Shimadzu Co. Ltd.) and a gas chromatograph mass (GC-17A GCMS-QP5050) equipped with a DB-Wax capillary column. The gas products were analyzed by gas chromatographs with thermal conductivity and flame ionization detectors (GC-8A; Shimadzu 
Co. Ltd.) equipped with activated charcoal and Porapak Q columns, respectively. The product yields were calculated based on the amount of glycerol fed to the reactor.

\section{Results and Discussion}

\section{$5 \quad$ 3.1. Catalytic reactions over alkali metal-supported $\mathrm{ZrO}_{2}-\mathrm{FeO}_{\mathrm{x}}$}

In a biodiesel fuel production process, alkali metals such as sodium $(\mathrm{Na})$ or potassium $(\mathrm{K})$

hydroxides are used as catalysts in the transesterification reaction. Therefore, crude glycerol, a waste solution obtained in a biodiesel fuel production process, contains these alkali metal ions. In a catalytic conversion of crude glycerol, these alkali metal ions are supposed to deposit on catalyst surface. Accordingly, the effect of loading of alkali metal on product yields was investigated. $\mathrm{ZrO}_{2}-\mathrm{FeO}_{\mathrm{X}}$ and $\mathrm{Na}-, \mathrm{K}-, \mathrm{Rb}-$, and $\mathrm{Cs}$-supported $\mathrm{ZrO}_{2}-\mathrm{FeO}_{\mathrm{X}}$ were used to convert $30 \mathrm{wt} \%$ glycerol solution for $6 \mathrm{~h}$ at $W / F$ of $3 \mathrm{~h}$. Table 1 shows the product yields of the Pathway I (allyl alcohol and propylene), the Pathway II (acetol, carboxylic acids, and ketones), and aldehydes (acrolein and acetaldehyde) obtained when $\mathrm{ZrO}_{2}-\mathrm{FeO}_{\mathrm{X}}$ and different alkali metal-supported $\mathrm{ZrO}_{2}-\mathrm{FeO}_{\mathrm{X}}$ were used for the glycerol conversion.

Almost complete glycerol conversions were attained for $\mathrm{ZrO}_{2}-\mathrm{FeO}_{\mathrm{X}}$ and all alkali metal-supported $\mathrm{ZrO}_{2}-\mathrm{FeO}_{\mathrm{X}}$, which indicated that alkali metals do not significantly influence the glycerol conversion. $\quad \mathrm{ZrO}_{2}-\mathrm{FeO}_{\mathrm{X}}$ yielded approximately $20 \mathrm{~mol} \%-\mathrm{C}$ of the Pathway $\mathrm{I}, 32$ 
mol\%-C of the Pathway II, and 10 mol\%-C of aldehydes. In comparison, all alkali metal-supported $\mathrm{ZrO}_{2}-\mathrm{FeO}_{\mathrm{X}}$ showed higher product yields of the Pathway I (24-25 mol\%-C), and remarkably lower product yields of the Pathway II (23-26 mol\%-C) and aldehydes (6-8 mol\%-C). Interestingly, allyl alcohol yield considerably increased from $13.7 \mathrm{~mol} \%$-C to approximately $20 \mathrm{~mol} \%-\mathrm{C}$.

Among the all alkali metals investigated, $\mathrm{K}$ was selected for the further studies because it showed relatively high Pathway I yield. Effect of K content on the dehydration of glycerol was studied. $\mathrm{K}[\mathrm{Z}] / \mathrm{ZrO}_{2}-\mathrm{FeO}_{\mathrm{X}}$, where $\mathrm{K}$ content $\mathrm{Z}$ varied from 0 to $10 \mathrm{~mol} \%$, was used to convert $30 \mathrm{wt} \%$ glycerol solution for $2 \mathrm{~h}$ at $W / F$ of $1 \mathrm{~h}$. Fig. 2 shows the glycerol conversions and the product yields obtained for $\mathrm{K}[\mathrm{Z}] / \mathrm{ZrO}_{2}-\mathrm{FeO}_{\mathrm{X}}(\mathrm{Z}=0-10 \mathrm{~mol} \%)$. The glycerol conversions maintained higher than $96 \%$ over the K content of $0-5 \mathrm{~mol} \%$ but the further increase in $\mathrm{K}$ content caused a moderate drop in the conversion down to $84 \%$. This could be explained by the coverage of the active sites of $\mathrm{ZrO}_{2}-\mathrm{FeO}_{\mathrm{X}}$ with the excessive amount of $\mathrm{K}$ existed on the catalyst. Notably, adding $\mathrm{K}$ on $\mathrm{ZrO}_{2}-\mathrm{FeO}_{\mathrm{X}}$ and the increase in its content resulted in a remarkable increase in allyl alcohol yield up to $27 \mathrm{~mol} \%$ - $\mathrm{C}$ at the $\mathrm{K}$ content of 3-5 mol\%. Furthermore, the addition of $\mathrm{K}$ led a drastic decrease in acetol, carboxylic acids, ketones, and aldehydes yields and this trend was notable at the higher $\mathrm{K}$ content. Regarding the selectivity to allyl alcohol, $\mathrm{K}[5] / \mathrm{ZrO}_{2}-\mathrm{FeO}_{\mathrm{X}}$ was concluded to be the 
catalyst having the most suitable $\mathrm{K}$ content and selected for the further studies. Furthermore, these results indicate that the glycerol dehydration, the Pathway II and the aldehydes formations, is effectively suppressed by the addition of K. Since the glycerol dehydration is considered to proceed on acid sites of catalysts, its suppression should be resulted from the decreased acidic property of the catalyst.

To confirm this, temperature-programmed desorption of ammonia ( $\mathrm{NH}_{3}$-TPD) was carried out to study the acidic properties of $\mathrm{ZrO}_{2}-\mathrm{FeO}_{\mathrm{X}}, \mathrm{K}[1] / \mathrm{ZrO}_{2}-\mathrm{FeO}$, and $\mathrm{K}[5] / \mathrm{ZrO}_{2}-\mathrm{FeO}_{\mathrm{X}}$. The amount of desorbed $\mathrm{NH}_{3}$ for $\mathrm{ZrO}_{2}-\mathrm{FeO}_{\mathrm{X}}$ was approximately 0.07 mmol kg-cat ${ }^{-1}$ while those for $\mathrm{K}[1] / \mathrm{ZrO}_{2}-\mathrm{FeO}_{\mathrm{X}}$ and $\mathrm{K}[5] / \mathrm{ZrO}_{2}-\mathrm{FeO}_{\mathrm{X}}$ were reduced to $0.01 \mathrm{mmol} \mathrm{kg}$-cat ${ }^{-1}$ or less as shown in Fig. 3. The amount of desorbed $\mathrm{NH}_{3}$ impressively decreased with the increase in $\mathrm{K}$ content, which in turn resulted in the further decrease in the acidic property of the catalyst. Additionally, the peak position of the $\mathrm{NH}_{3}$-TPD profile was shifted to the lower temperature as the amount of $\mathrm{K}$ content increased. These results indicated that the acidic property of $\mathrm{ZrO}_{2}-\mathrm{FeO}_{\mathrm{X}}$ had been lowered by the addition of $\mathrm{K}$, which in turn led to the suppression of the glycerol dehydration.

The catalyst acidity is assumed to be derived from the hydroxyl groups exit on the catalyst surface which allows the glycerol dehydration to proceed. Although most acid sites were removed from the catalyst by the addition of $\mathrm{K}$, significant amount of the dehydration products 
(Pathway II and aldehydes) was still obtained. The hydroxyl groups should be partly covered the alkali metals which suppressed the glycerol dehydration. However, acidic sites of the catalysts should be still remained for the glycerol dehydration to proceed to a minor extent. Also, according to Auroux et al., the conversion of glycerol to acetol can proceed over basic 5 sites of catalysts through either dehydrogenation and consecutive dehydration and hydrogenation, or through dehydration of a terminal hydroxyl group of glycerol to form enol intermediate which can be rapidly rearranged to form acetol [29].

Since it is considered that the Pathway II, the acetol production, and the aldehydes production proceeded through the dehydration of glycerol on acidic sites of catalysts, these reactions were suppressed by the addition of $\mathrm{K}$. On the other hand, it substantially promoted the Pathway I which is the allyl alcohol production. Unlike the formations of acetol and aldehydes, allyl alcohol is assumed to be catalyzed by non-acidic sites of catalysts which should proceed through hydrogen transfer mechanism [13-14]. Schuth et al. and Xu et al. reported acrolein to be an intermediate to allyl alcohol in which acrolein hydrogenates to form

15 allyl alcohol $[13,26]$. However, based on our investigations this idea is highly unlikely for our reaction system. Firstly, no external hydrogen gas was supplied to our reaction system. Secondly, we conducted the catalytic conversion of pure acrolein aqueous solution over $\mathrm{K}[5] / \mathrm{ZrO}_{2}-\mathrm{FeO}_{\mathrm{X}}$ and no allyl alcohol was observed in the products as shown in Table 2. 
Instead, acrolein was mostly converted into the hydrocarbons undetectable by GC with the conversion of $98 \%$ which are supposed to be the acrolein polymers.

On the other hand, the hydrogen transfer mechanism to form allyl alcohol possibly takes place in the reactions between glycerol and other intermediates forming during the reaction.

5 To confirm this, we pumped glycerol aqueous solution with acetol, acrolein, acetic acid, or formic acid aqueous solutions through the reactor at $W / F$ of $3 \mathrm{~h}$, where $F$ is the feed rate of glycerol solution. $\mathrm{K}[5] / \mathrm{ZrO}_{2}-\mathrm{FeO}_{\mathrm{X}}$ was used as a catalyst. The glycerol conversions and propylene and allyl alcohol yields obtained from glycerol are shown in Table 3. The full glycerol conversions and comparable propylene yields were obtained for all reactions. When acrolein or acetic acid was added to the system, allyl alcohol yield did not increase, which excluded the possibility of the hydrogen transfer reactions between glycerol and acrolein or acetic acid. To be noted, allyl alcohol yield slightly increased when acetol was added and remarkably increased up to $33 \mathrm{~mol} \%-\mathrm{C}$ with the addition of formic acid. Formic acid should be formed during the reaction by two possible ways. Firstly, glycerol can dehydrate to form 15 the unstable intermediate 3-hydroxypropionaldehyde (3-HPA). While 3-HPA can further dehydrate to produce acrolein, it can also decompose to obtain acetaldehyde and formaldehyde through a reversed aldol condensation [26]. The follow up oxidation of formaldehyde with the lattice oxygen of $\mathrm{FeO}_{\mathrm{X}}$ can give formic acid. Another possible way would be that acetol 
formed from the glycerol dehydration can oxidatively decompose with the lattice oxygen of $\mathrm{FeO}_{\mathrm{X}}$ to give acetic acid and formic acid while acetol can be also isomerized to form propionic acid [30]. Formic acid can further decompose into $\mathrm{CO}_{2}$ and $\mathrm{H}_{2}$ over a catalyst and during this catalytic decomposition hydrogen atoms are possibly formed [31]. Therefore, these hydrogen atoms derived from formic acid seems to play an important role in our current reaction system and the hydrogen transfer reaction likely takes place between glycerol and the hydrogen atoms. This well explained the increased allyl alcohol yield with the addition of acetol or formic acid to the system in Table 3.

Another possible mechanism of hydrogen transfer reaction would be the reaction between consider that $\mathrm{ZrO}_{2}-\mathrm{FeO}_{\mathrm{X}}$ has an ability to decompose $\mathrm{H}_{2} \mathrm{O}$ molecules into active hydrogen species $[23,25]$. These active hydrogen species can act as the hydrogen atoms derived from formic acid and play an important role for the formation of allyl alcohol. However, further investigation on a detailed mechanism of the allyl alcohol production is still ongoing in our laboratory.

\subsection{Stability of K-supported $\mathrm{FeO}_{\mathrm{x}}$ catalyst}

The catalytic reaction of $30 \mathrm{wt} \%$ glycerol solution was performed for $6 \mathrm{~h}$ and $W / F$ of $1 \mathrm{~h}$ to 
examine stability of $\mathrm{K}[5] / \mathrm{ZrO}_{2}-\mathrm{FeO}_{\mathrm{X}}$. As shown in Fig. 4(a), initial glycerol conversion and allyl alcohol yield were $96 \%$ and 26 mol\%-C, respectively. However, glycerol conversion and allyl alcohol yield drastically decreased to $65 \%$ and 14 mol\%-C with the increase in reaction time. On the other hand, the Pathway II and aldehydes yields maintained approximately $12 \mathrm{~mol} \%$-C and $7 \mathrm{~mol} \%$-C, respectively, over $6 \mathrm{~h}$. For the further study of this result, the $\mathrm{K}$ content in $\mathrm{K}[5] / \mathrm{ZrO}_{2}-\mathrm{FeO}_{\mathrm{X}}$ after the catalytic reaction was investigated with an $\mathrm{X}$-ray fluorescence analyzer in our laboratory. It confirmed that the $\mathrm{K}$ content still maintained $5 \mathrm{~mol} \%$ of the total $\mathrm{Zr}$ and $\mathrm{Fe}$ after the catalytic reaction for $6 \mathrm{~h}$. This well explained the stable yields of the Pathway II and aldehydes over $6 \mathrm{~h}$.

Fig. 5 shows the XRD patterns of $\mathrm{K}[5] / \mathrm{ZrO}_{2}-\mathrm{FeO}_{\mathrm{X}}$ before and after the reaction. The crystal phase of $\mathrm{K}[5] / \mathrm{ZrO}_{2}-\mathrm{FeO}_{\mathrm{X}}$ before the reaction was hematite structure. However, that of $\mathrm{K}[5] / \mathrm{ZrO}_{2}-\mathrm{FeO}_{\mathrm{X}}$ after the reaction for $6 \mathrm{~h}$ showed magnetite structure due to the excessive consumption of the lattice oxygen of iron oxide [24-25]. Such change in the crystal phase of the catalyst should be responsible for the reduced catalytic activity and the decreased glycerol conversion and allyl alcohol yield.

In order to maintain high catalytic activity, the suppression of the excessive consumption of the lattice oxygen seems to be beneficial. This could be achieved by calcining the catalyst at higher temperature. However, one controversial point would be that calcination of a catalyst 
at high temperature may lead to a decrease in surface area of a catalyst [32]. In fact, our investigations showed that the $\mathrm{BET}$ surface area of $\mathrm{K}[5] / \mathrm{ZrO}_{2}-\mathrm{FeO}_{\mathrm{X}}$ drastically decreased from $51 \mathrm{~m}^{2} \mathrm{~g}^{-1}$ to $14 \mathrm{~m}^{2} \mathrm{~g}^{-1}$ with the increase in calcination temperature from $773 \mathrm{~K}$ to $973 \mathrm{~K}$, while crystal phase of both catalysts showed hematite structure. This significant decrease in the

surface area should result from sintering of $\mathrm{FeO}_{\mathrm{X}}$ during calcination. To avoid this negative influence of the higher calcination temperature, $\mathrm{Al}_{2} \mathrm{O}_{3}$ seems to be the key material since our previous study has revealed that addition of $\mathrm{Al}_{2} \mathrm{O}_{3}$ to $\mathrm{FeO}_{\mathrm{X}}$ was effective in increasing surface area and stability of the $\mathrm{FeO}_{\mathrm{X}}$ catalyst for upgrading heavy oil $[24,33]$.

\subsection{Characterization and catalytic activity of $\mathrm{K}[5] / \mathrm{Al}_{2} \mathrm{O}_{3}-\mathrm{ZrO}_{2}-\mathrm{FeO}_{\mathrm{x}}$}

In this study, addition of $\mathrm{Al}_{2} \mathrm{O}_{3}$ to $\mathrm{K} / \mathrm{ZrO}_{2}-\mathrm{FeO}_{\mathrm{X}}$ was examined. In consideration of structure stability and surface area of the catalyst, calcining the catalyst at higher temperature and adding $\mathrm{Al}_{2} \mathrm{O}_{3}$ to the catalyst appears to be advantageous to attain high glycerol conversion and allyl alcohol yield. Therefore, we now developed $\mathrm{K}[5] / \mathrm{Al}_{2} \mathrm{O}_{3}-\mathrm{ZrO}_{2}-\mathrm{FeO}_{\mathrm{X}}$. to catalytic reaction are compared in Fig. 5. The crystal phases of both catalysts were hematite structure. Although $\mathrm{K}[5] / \mathrm{Al}_{2} \mathrm{O}_{3}-\mathrm{ZrO}_{2}-\mathrm{FeO}_{\mathrm{X}}$ was calcined at higher temperature of $973 \mathrm{~K}$, it was shown to have even higher BET surface area $\left(62 \mathrm{~m}^{2} \mathrm{~g}^{-1}\right)$ than $\mathrm{K}[5] / \mathrm{ZrO}_{2}-\mathrm{FeO}_{\mathrm{X}}$. 
This phenomenon is ascribed mainly to the addition of $\mathrm{Al}_{2} \mathrm{O}_{3}$ to $\mathrm{K} / \mathrm{ZrO}_{2}-\mathrm{FeO}_{\mathrm{X}} \cdot \mathrm{Al}_{2} \mathrm{O}_{3}$ among the $\mathrm{FeO}_{\mathrm{X}}$ crystals suppressed the sintering of the $\mathrm{FeO}_{\mathrm{X}}$ and, consequently, high BET surface area of the catalyst was achieved.

Catalytic conversion of $30 \mathrm{wt} \%$ glycerol was performed over $\mathrm{K}[5] / \mathrm{Al}_{2} \mathrm{O}_{3}-\mathrm{ZrO}_{2}-\mathrm{FeO}_{\mathrm{X}}$.

5 The product yields for $\mathrm{K}[5] / \mathrm{ZrO}_{2}-\mathrm{FeO}_{\mathrm{X}}$ and $\mathrm{K}[5] / \mathrm{Al}_{2} \mathrm{O}_{3}-\mathrm{ZrO}_{2}-\mathrm{FeO}_{\mathrm{X}}$ are compared in Fig. 4. As observed in Fig. 4(b), almost no glycerol could be observed in the products for $\mathrm{K}[5] / \mathrm{Al}_{2} \mathrm{O}_{3}-\mathrm{ZrO}_{2}-\mathrm{FeO}_{\mathrm{X}}$ at the initial reaction period $(0-2 \mathrm{~h})$. To our delight, the high glycerol conversion of $87 \%$ was attained after $6 \mathrm{~h}$. Allyl alcohol yield also maintained approximately $25 \mathrm{~mol} \%$-C over $6 \mathrm{~h}$. In general, $\mathrm{Al}_{2} \mathrm{O}_{3}$ possesses an acid site which would have an effect on the glycerol dehydration. Interestingly, the product yields of the Pathway II and aldehydes for $\mathrm{K}[5] / \mathrm{Al}_{2} \mathrm{O}_{3}-\mathrm{ZrO}_{2}-\mathrm{FeO}_{\mathrm{X}}$ were $9-11 \mathrm{~mol} \%-\mathrm{C}$ and 5-9 mol\%-C respectively, and these yields were equivalent to those for $\mathrm{K}[5] / \mathrm{ZrO}_{2}-\mathrm{FeO}$. In $\mathrm{K}[5] / \mathrm{Al}_{2} \mathrm{O}_{3}-\mathrm{ZrO}_{2}-\mathrm{FeO}_{\mathrm{X}}$, because $\mathrm{K}$ was loaded on $\mathrm{Al}_{2} \mathrm{O}_{3}-\mathrm{ZrO}_{2}-\mathrm{FeO}_{\mathrm{X}}$ by an impregnation method, the acidity derived from $\mathrm{Al}_{2} \mathrm{O}_{3}$ relatively weakened. Accordingly, $\mathrm{Al}_{2} \mathrm{O}_{3}$ contributed in an impressive increase in surface area and stability of the catalyst without any negative influence on the catalyst acidity. To summarize, $\mathrm{K}[5] / \mathrm{Al}_{2} \mathrm{O}_{3}-\mathrm{ZrO}_{2}-\mathrm{FeO}_{\mathrm{X}}$ maintained much higher glycerol conversion and allyl alcohol yield over the $6 \mathrm{~h}$ reaction compared to $\mathrm{K}[5] / \mathrm{ZrO}_{2}-\mathrm{FeO}_{\mathrm{X}}$ and showed incredibly higher catalytic stability. 
XRD patterns of $\mathrm{K}[5] / \mathrm{ZrO}_{2}-\mathrm{FeO}_{\mathrm{X}}$ and $\mathrm{K}[5] / \mathrm{Al}_{2} \mathrm{O}_{3}-\mathrm{ZrO}_{2}-\mathrm{FeO}_{\mathrm{X}}$ after the catalytic conversion for $6 \mathrm{~h}$ are shown in Fig. 5. The crystal phase of $\mathrm{K}[5] / \mathrm{ZrO}_{2}-\mathrm{FeO}_{\mathrm{X}}$ was changed from hematite into magnetite structure after the reaction due to the consumption of the lattice oxygen of iron oxide while $\mathrm{K}[5] / \mathrm{Al}_{2} \mathrm{O}_{3}-\mathrm{ZrO}_{2}-\mathrm{FeO}_{\mathrm{X}}$ still kept hematite structure. This high structure stability of $\mathrm{K}[5] / \mathrm{Al}_{2} \mathrm{O}_{3}-\mathrm{ZrO}_{2}-\mathrm{FeO}_{\mathrm{X}}$ well explained the high catalytic stability of the catalyst for allyl alcohol production.

\subsection{Catalytic conversion of crude glycerol solution over $\mathrm{K}[5] / \mathrm{Al}_{2} \mathrm{O}_{3}-\mathrm{ZrO}_{2}-\mathrm{FeO}_{\mathrm{X}}$}

Crude glycerol solution is the waste solution obtained in the process of biodiesel fuel production which contains impurities such as methanol, free fatty acids, ash and water [34]. According to the analysis by a gas chromatograph and an X-ray fluorescence analyzer, crude glycerol was found to consist mainly of glycerol (37 wt $\%$ ), methanol (8wt\%), potassium (4 wt $\%$ ), others including free fatty acids ( $25 \mathrm{wt} \%)$, and components undetectable by GC (26 wt $\%)$. The crude glycerol was diluted with distilled water and $10 \mathrm{wt} \%$ of its solution was conversion of $10 \mathrm{wt} \%$ crude glycerol solution at $W / F$ of $5 \mathrm{~h}$, where $F$ was referred to as the flow rate of the feedstock $\left(\mathrm{g} \mathrm{h}^{-1}\right)$ of crude glycerol solution.

As shown in Fig. 6, useful chemicals such as propylene, allyl alcohol, acetol, carboxylic 
acids, and ketones were obtained in accordance with the reaction pathways shown in Fig. 1.

Although crude glycerol contains impurities, it successfully produced useful chemicals including allyl alcohol over $\mathrm{K}[5] / \mathrm{Al}_{2} \mathrm{O}_{3}-\mathrm{ZrO}_{2}-\mathrm{FeO}_{\mathrm{X}}$. Initial allyl alcohol yield was 25 mol\%-C and its highest yield of $33 \mathrm{~mol} \%-\mathrm{C}$ was achieved at the reaction time of $2-4 \mathrm{~h}$. At

5 the reaction time of 4-6 h the allyl alcohol yield still kept as high as 29 mol\%-C. The other components in crude glycerol such as free fatty acids and methanol should be degraded during the catalytic reaction. To be noted, the catalyst has the lattice oxygen which can oxidize free fatty acids and methanol into $\mathrm{CO}_{2}$ and other degraded products. However, these degraded products were not analyzed in this experiment. Thus, they were not included in the product 10 yields in Fig. 6 since the product yields were calculated based on the amount of glycerol fed to the reactor.

Fig. 7 shows $\mathrm{XRD}$ patterns of $\mathrm{K}[5] / \mathrm{Al}_{2} \mathrm{O}_{3}-\mathrm{ZrO}_{2}-\mathrm{FeO}_{\mathrm{X}}$ before and after the catalytic conversion of crude glycerol. The crystal phase of the catalyst before the reaction was hematite structure and the structure was maintained after the reaction. This indicates that the 15 lattice oxygen of $\mathrm{FeO}_{\mathrm{x}}$ consumed during the oxidation of free fatty acids and methanol are successfully regenerated by $\mathrm{ZrO}_{2}[24,25]$. These results show that $\mathrm{K}[5] / \mathrm{Al}_{2} \mathrm{O}_{3}-\mathrm{ZrO}_{2}-\mathrm{FeO}_{\mathrm{X}}$ is adequately applicable to the conversion of crude glycerol regardless of its contamination of various impurities. 


\section{Conclusions}

In this work, catalytic conversion of glycerol was performed under nitrogen gas flow with different iron oxide-based catalysts to achieve high allyl alcohol yield. Different alkali metals,

5 including $\mathrm{Na}, \mathrm{K}, \mathrm{Rb}$, and $\mathrm{Cs}$ were supported on $\mathrm{ZrO}_{2}-\mathrm{FeO}_{\mathrm{X}}$ with the intent to suppress glycerol dehydration proceeded on the acid sites of the catalyst. All alkali metal-supported $\mathrm{ZrO}_{2}-\mathrm{FeO}_{\mathrm{X}}$ gave considerably higher allyl alcohol yield and suppressed glycerol dehydration.

$\mathrm{K}$-supported $\mathrm{ZrO}_{2}-\mathrm{FeO}_{\mathrm{X}}$ was selected for further studies regarding allyl alcohol yield. With the increase in $\mathrm{K}$ content allyl alcohol yield increased up to $27 \mathrm{~mol} \%-\mathrm{C}$ and dehydration products yield drastically decreased. This could be explained by the decreased acidic property of the catalyst by the addition of $\mathrm{K}$. While the glycerol dehydration proceeds on acid sites of catalysts, allyl alcohol is assumed to be produced over non-acidic sites through a hydrogen transfer mechanism. Considering the fact that no external hydrogen is added to the system, the hydrogen transfer mechanism should take place between the reaction of glycerol and either hydrogen atoms derived from formic acid forming during the reaction, or active hydrogen species produced from the decomposition of $\mathrm{H}_{2} \mathrm{O}$ by $\mathrm{ZrO}_{2}$.

To maintain structure stability of the catalyst to obtain higher allyl alcohol yield and glycerol conversion, $\mathrm{K}[5] / \mathrm{Al}_{2} \mathrm{O}_{3}-\mathrm{ZrO}_{2}-\mathrm{FeO}_{\mathrm{X}}$ was developed. The catalyst was verified to 
have almost the same surface area and crystal phase with $\mathrm{K}[5] / \mathrm{ZrO}_{2}-\mathrm{FeO}$. $\mathrm{K}[5] / \mathrm{Al}_{2} \mathrm{O}_{3}-\mathrm{ZrO}_{2}-\mathrm{FeO}_{\mathrm{x}}$ showed much higher structure stability and maintained remarkably higher allyl alcohol yield of 25 mol\%-C and glycerol conversion of $87 \%$ over $6 \mathrm{~h}$ compared to $\mathrm{K}[5] / \mathrm{ZrO}_{2}-\mathrm{FeO}_{\mathrm{x}}$ without any negative effect on catalyst acidity. Furthermore, $5 \mathrm{~K}[5] / \mathrm{Al}_{2} \mathrm{O}_{3}-\mathrm{ZrO}_{2}-\mathrm{FeO}_{\mathrm{X}}$ was applicable to the conversion of crude glycerol which is the waste solution obtained from biodiesel production containing impurities such as methanol, free fatty acids, ash, and water. The catalyst maintained the crystal phase of hematite structure over $6 \mathrm{~h}$ which indicated the lattice oxygen of $\mathrm{FeO}_{\mathrm{X}}$ consumed during the oxidation of free fatty acids and methanol were successfully regenerated by $\mathrm{ZrO}_{2}$ in the presence of the impurities in crude 10 glycerol.

\section{Acknowledgements}

This work was supported by the Industrial Technology Research Grant Program in 2008, 08B36001c from the New Energy and Industrial Technology Development Organization 15 (NEDO) of Japan.

\section{References}

1. F. Ma, M.A. Hanna, Bioresource Technol. 70 (1999) 1-15. 
2. H. Fukuda, A. Kondo, H. Noda, J. Biosci. Bioeng. 92 (2001) 405-416.

3. L.C. Meher, D.V. Sagar, S.N. Naik, Renew. Sust. Energ. Rev. 10 (2006) 248-268.

4. H. Fukuda, A. Kondo, H. Noda, J. Biosci. Bioeng. 92 (2001) 405-416.

5. A. Behr, J. Eilting, K. Irawadi, J. Leschinski, F. Lindner, Green Chem. 10 (2008) 13-30.

$5 \quad$ 6. S.H. Chai, H.P. Wang, Y. Liang, B.Q. Xu, J. Catal. 250 (2007) 342-349.

7. E. Tsukuda, S. Sato, R. Takahashi, T. Sodesawa, Catal. Commun. 8 (2007) 1349-1353.

8. A. Corma, G.W. Huber, L. Sauvanaud, P. O’Connor, J. Catal. 257 (2008) 163-171.

9. S. Sato, M. Akiyama, R. Takahashi, T. Hara, K. Inui, M. Yokota, Appl. Catal. A-Gen. 347 (2008) 186-191.

10. T. Miyazawa, S. Koso, K. Kunimori, K. Tomishige, Appl. Catal. A-Gen. 329 (2007) $30-35$.

11. D.G. Lahr, B.H. Shanks, J. Catal. 232 (2005) 386-394.

12. T. Kurosaka, H. Maruyama, I. Naribayashi, Y. Sasaki, Catal. Commun. 9 (2008) $1360-1363$. Chem. Commun. 46 (2010) 1238-1240.

14. J. Yi, S. Liu, M. M. Abu-Omar, Chem. Sus. Chem. 5 (2012) 1401-1404.

15. M. Shiramizu, F. D. Toste, Angew. Chem. Int. Ed. 51 (2012) 8082-8086. 
16. L. Qadariyah, Mahfud, Sumarno, S. Machmudah, Wahyudiono, M. Sasaki, M. Goto, Bioresource Technol. 102 (2011) 9267-9271.

17. T. Masuda, Y. Kondo, M. Miwa, T. Shimotori, S.R. Mukai, K. Hashimoto, M. Takano, S. Kawasaki, S. Yoshida, Chem. Eng. Sci. 56 (2001) 897-904. 426-430.

19. T. Yoshikawa, D. Na-Ranong, T. Tago, T. Masuda, J. Jpn. Petrol. Inst. 53 (2010) 178-183.

20. D. Mansur, T. Yoshikawa, K. Norinaga, J. Hayashi, T. Tago, T. Masuda, Fuel. in press

21. E. Fumoto, Y. Mizutani, T. Tago, T. Masuda, Appl. Catal. B: Environ. 68 (2006) 154-159. $654-658$

23. T. Yoshikawa, T. Tago, A. Nakamura, A. Konaka, M. Mukaida, T. Masuda, Res. Chem. Intermed. 37 (2011) 1247-1256.

24. S. Funai, E. Fumoto, T. Tago, T. Masuda, Chem. Eng. Sci. 65 (2010) 60-65.

26. S.H. Chai, H.P. Wang, Y. Liang, B.Q. Xu, Green Chem. 9 (2007) 1130-1136.

27. W. Suprun, M. Lutecki, T. Haber, H. Papp, J. Mol. Catal. A: Chem. 309 (2009) 71-78.

28. K. Pathak, M. Reddy, N.N. Bakhshi, A.K. Dalai, Appl. Catal. A: Gen. 372 (2010) 
224-234.

29. D. Stosic, S. Bennici, J.L. Couturier, J.L. Dubois, A. Auroux, Catal. Commun. 17 (2012) 23-28.

30. D.J. Hopper, E.A. Elmorsi, Biochem. J. 218 (1984) 269-272.

31. I. Gandarias, P.L. Arias, S.G. Fernandez, J. Requies, M.E. Doukkali, M.B. Guemez, Catal. Today. 195 (2012) 22-31.

32. J.M. Jehng, I.E. Wachs, J. Mol. Catal. 81 (1993) 63-75.

33. E. Fumoto, T. Tago, T. Masuda, Energ. Fuel. 20 (2006) 1-6.

34. M. Ayoub, A.Z. Abdullah, Renew. Sust. Energ. Rev. 16 (2012) 2671-2686. 


\section{Figure and Table captions}

Figure 1. Expected reaction pathways for glycerol over $\mathrm{ZrO}_{2}-\mathrm{FeO}_{\mathrm{X}}$.

Figure 2. Effect of $\mathrm{K}$ content on the product yields

5 Reaction conditions: $30 \mathrm{wt} \%$ glycerol solution, $\mathrm{K}[\mathrm{Z}] / \mathrm{ZrO}_{2}-\mathrm{FeO} \mathrm{X}(\mathrm{Z}=0-10 \mathrm{~mol} \%), W / F=1 \mathrm{~h}$, Reaction time $=2 \mathrm{~h}$.

Figure 3. $\mathrm{NH}_{3}-\mathrm{TPD}$ profiles for $\mathrm{ZrO}_{2}-\mathrm{FeO}_{\mathrm{X}}, \mathrm{K}[1] / \mathrm{ZrO}_{2}-\mathrm{FeO}$, and $\mathrm{K}[5] / \mathrm{ZrO}_{2}-\mathrm{FeO}_{\mathrm{X}}$.

Figure 4(a). Stability of $\mathrm{K}[5] / \mathrm{ZrO}_{2}-\mathrm{FeO}_{\mathrm{X}}$

Reaction conditions: $30 \mathrm{wt} \%$ glycerol solution, $\mathrm{K}[5] / \mathrm{ZrO}_{2}-\mathrm{FeO}_{\mathrm{x}}, W / F=1 \mathrm{~h}$, Reaction time $=6$ h.

Figure 4(b). Stability of $\mathrm{K}[5] / \mathrm{Al}_{2} \mathrm{O}_{3}-\mathrm{ZrO}_{2}-\mathrm{FeO}_{\mathrm{X}}$

15 Reaction conditions: $30 \mathrm{wt} \%$ glycerol solution, $\mathrm{K}[5] / \mathrm{Al}_{2} \mathrm{O}_{3}-\mathrm{ZrO}_{2}-\mathrm{FeO}_{\mathrm{X}}, W / F=3 \mathrm{~h}$, Reaction time $=6 \mathrm{~h}$.

Figure 5. XRD patterns of $\mathrm{K}[5] / \mathrm{ZrO}_{2}-\mathrm{FeO}_{\mathrm{X}}$ and $\mathrm{K}[5] / \mathrm{Al}_{2} \mathrm{O}_{3}-\mathrm{ZrO}_{2}-\mathrm{FeO}_{\mathrm{X}}$ before and after the 
catalytic reaction.

Reaction conditions: $30 \mathrm{wt} \%$ glycerol solution, $W / F=1 \mathrm{~h}$, Reaction time $=6 \mathrm{~h}$.

Figure 6. Catalytic conversion of crude glycerol using $\mathrm{K}[5] / \mathrm{Al}_{2} \mathrm{O}_{3}-\mathrm{ZrO}_{2}-\mathrm{FeO}_{\mathrm{X}}$

5 Reaction conditions: $10 \mathrm{wt} \%$ crude glycerol solution, $\mathrm{K}[5] / \mathrm{Al}_{2} \mathrm{O}_{3}-\mathrm{ZrO}_{2}-\mathrm{FeO}_{\mathrm{X}}, W / F=5 \mathrm{~h}$, Reaction time $=6 \mathrm{~h}$

Figure 7. XRD patterns of $\mathrm{K}[5] / \mathrm{Al}_{2} \mathrm{O}_{3}-\mathrm{ZrO}_{2}-\mathrm{FeO}_{\mathrm{X}}$ before and after catalytic reaction of crude glycerol

Reaction conditions: $10 \mathrm{wt} \%$ crude glycerol solution, $W / F=5 \mathrm{~h}$, Reaction time $=6 \mathrm{~h}$.

Table 1. Product yields obtained for different alkali metal-supported $\mathrm{ZrO}_{2}-\mathrm{FeO}_{\mathrm{X}}$

Reaction conditions: $30 \mathrm{wt} \%$ glycerol solution, alkali metal-supported $\mathrm{ZrO}_{2}-\mathrm{FeO}_{\mathrm{X}}, W / F=3 \mathrm{~h}$,

Reaction time $=6 \mathrm{~h}$.

Table 2. Product yields obtained for different model compounds.

Reaction conditions: $\mathrm{K}[5] / \mathrm{ZrO}_{2}-\mathrm{FeO}_{\mathrm{X}}, W / F=3 \mathrm{~h}$, Reaction time $=2 \mathrm{~h}$. 
Table 3. Propylene and allyl alcohol yields for the reactions of glycerol and different intermediates.

Reaction conditions: $\mathrm{K}[5] / \mathrm{ZrO}_{2}-\mathrm{FeO}_{\mathrm{X}}, W / F=3 \mathrm{~h}$, Reaction time $=2 \mathrm{~h}$. 
Table 1. Product yields obtained for different alkali metal-supported $\mathrm{ZrO}_{2}-\mathrm{FeO}_{\mathrm{X}}$. Reaction conditions: $30 \mathrm{wt} \%$ glycerol solution, alkali metal-supported $\mathrm{ZrO}_{2}-\mathrm{FeO}_{\mathrm{X}}, W / F=3 \mathrm{~h}$, Reaction time $=6 \mathrm{~h}$.

\begin{tabular}{|c|c|c|c|c|c|c|c|c|c|c|c|}
\hline \multirow[t]{3}{*}{$\mathrm{ZrO}_{2}-\mathrm{FeOx}$} & \multirow{3}{*}{$\begin{array}{l}\text { Glycerol } \\
\text { conversion/\% }\end{array}$} & \multicolumn{10}{|c|}{ Product yield/mol\%-C } \\
\hline & & \multicolumn{3}{|l|}{ Path I } & \multicolumn{4}{|c|}{ Path II } & \multicolumn{3}{|c|}{ Aldehydes } \\
\hline & & Propylene & $\begin{array}{l}\text { Allyl } \\
\text { Alcohol }\end{array}$ & Path I & Acetol & $\begin{array}{l}\text { Carboxylic } \\
\text { Acids }\end{array}$ & Ketones & Path II & Acrolein & Acetaldehyde & Aldehydes \\
\hline- & 100 & 5.9 & 13.7 & 19.6 & 1.2 & 21.2 & 9.2 & 31.6 & 6.3 & 3.6 & 9.9 \\
\hline $\mathbf{N a}$ & 100 & 4.3 & 20.2 & 24.5 & 0.2 & 12.6 & 9.7 & 22.5 & 4.8 & 3.8 & 8.6 \\
\hline $\mathbf{K}$ & 98.8 & 4.4 & 20.7 & 25.1 & 2.1 & 13.8 & 8.1 & 24.0 & 3.9 & 2.7 & 6.6 \\
\hline $\mathbf{R b}$ & 100 & 4.8 & 19.6 & 24.4 & 0.0 & 11.4 & 11.7 & 23.1 & 3.6 & 3.4 & 7.0 \\
\hline Cs & 99.8 & 4.4 & 19.7 & 24.1 & 1.0 & 14.4 & 10.4 & 25.8 & 3.2 & 2.3 & 5.5 \\
\hline
\end{tabular}


Table 2. Product yields obtained for different model compounds.

Reaction conditions: $\mathrm{K}[5] / \mathrm{ZrO}_{2}-\mathrm{FeO}_{\mathrm{X}}, W / F=3 \mathrm{~h}$, Reaction time $=2 \mathrm{~h}$.

\begin{tabular}{|c|c|c|c|c|c|c|c|c|c|c|c|}
\hline \multirow{3}{*}{$\begin{array}{l}\text { Model } \\
\text { compound } \\
\text { (Concentration) }\end{array}$} & \multirow{3}{*}{ Conversion $/ \%$} & \multicolumn{10}{|c|}{ Product yield/mol\%-C } \\
\hline & & \multicolumn{2}{|l|}{ Path I } & \multicolumn{3}{|c|}{ Path II } & \multicolumn{2}{|c|}{ Aldehydes } & \multirow[t]{2}{*}{ Others } & \multirow{2}{*}{$\begin{array}{l}\text { Undetectable } \\
\text { by GC }\end{array}$} & \multirow[t]{2}{*}{$\mathrm{CO}_{2}$} \\
\hline & & Propylene & $\begin{array}{l}\text { Allyl } \\
\text { Alcohol }\end{array}$ & Acetol & $\begin{array}{l}\text { Carboxylic } \\
\text { Acids }\end{array}$ & Ketones & Acrolein & Acetaldehyde & & & \\
\hline $\begin{array}{l}\text { Glycerol } \\
(30 \mathrm{wt} \%)\end{array}$ & 100 & 0.6 & 25.4 & 0.4 & 3.6 & 7.4 & 0.5 & 3.0 & 12.2 & 33.5 & 13.4 \\
\hline $\begin{array}{l}\text { Acrolein } \\
(10 w t \%)\end{array}$ & 97.5 & 0.0 & 0.0 & 0.0 & 0.0 & 1.2 & - & 1.2 & 1.1 & 89.4 & 4.6 \\
\hline
\end{tabular}


Table 3. Propylene and allyl alcohol yields for the reactions of glycerol and different intermediates.

Reaction conditions: $\mathrm{K}[5] / \mathrm{ZrO}_{2}-\mathrm{FeO}_{\mathrm{X}}, W / F=3 \mathrm{~h}$, Reaction time $=2 \mathrm{~h}$.

\begin{tabular}{|c|c|c|c|}
\hline \multirow[t]{2}{*}{ Feedstock } & \multirow{2}{*}{$\begin{array}{l}\text { Glycerol } \\
\text { conversion/\% }\end{array}$} & \multicolumn{2}{|c|}{ Product yield $/ \mathrm{mol} \%-\mathrm{C}$} \\
\hline & & Propylene & $\begin{array}{l}\text { Allyl } \\
\text { Alcohol }\end{array}$ \\
\hline Glycerol & 100 & 0.6 & 25.4 \\
\hline $\begin{array}{l}\text { Glycerol } \\
\text { and Acetol }\end{array}$ & 100 & 1.3 & 28.4 \\
\hline $\begin{array}{l}\text { Glycerol } \\
\text { and Acrolein }\end{array}$ & 100 & 1.1 & 23.6 \\
\hline $\begin{array}{l}\text { Glycerol and } \\
\text { Acetic Acid }\end{array}$ & 100 & 1.0 & 26.7 \\
\hline $\begin{array}{l}\text { Glycerol and } \\
\text { Formic Acid }\end{array}$ & 100 & 1.1 & 33.4 \\
\hline
\end{tabular}

The glycerol concentrations were $30 \mathrm{wt} \%$ for all reactions. The concentrations of acetol and formic acid aqueous solutions were 30 $\mathrm{wt} \%$, and acrolein and acetic acid aqueous solutions were $20 \mathrm{wt} \%$. 


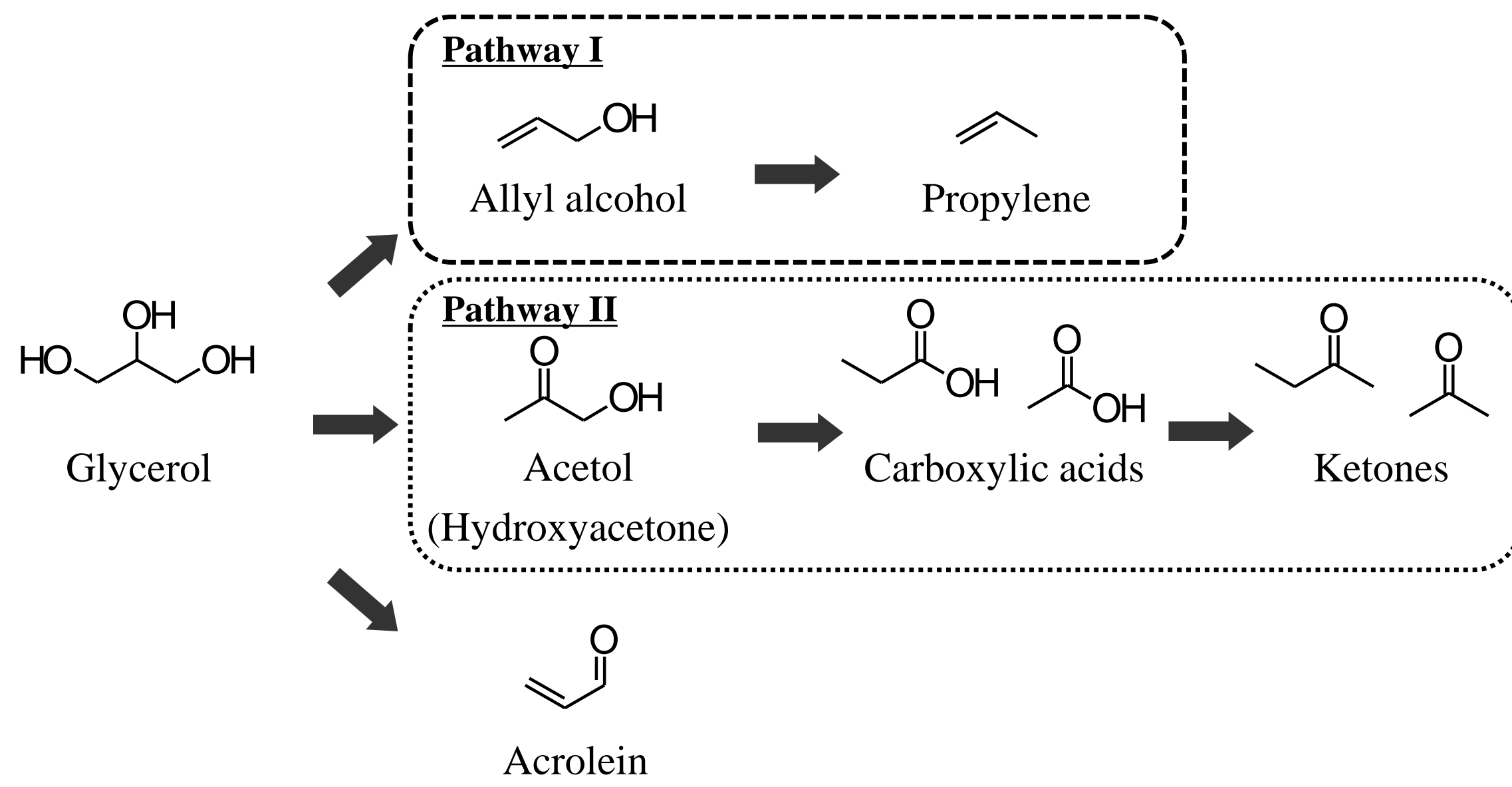

Figure 1. Expected reaction pathways for glycerol over $\mathrm{ZrO}_{2}-\mathrm{FeO}_{\mathrm{X}}$. 


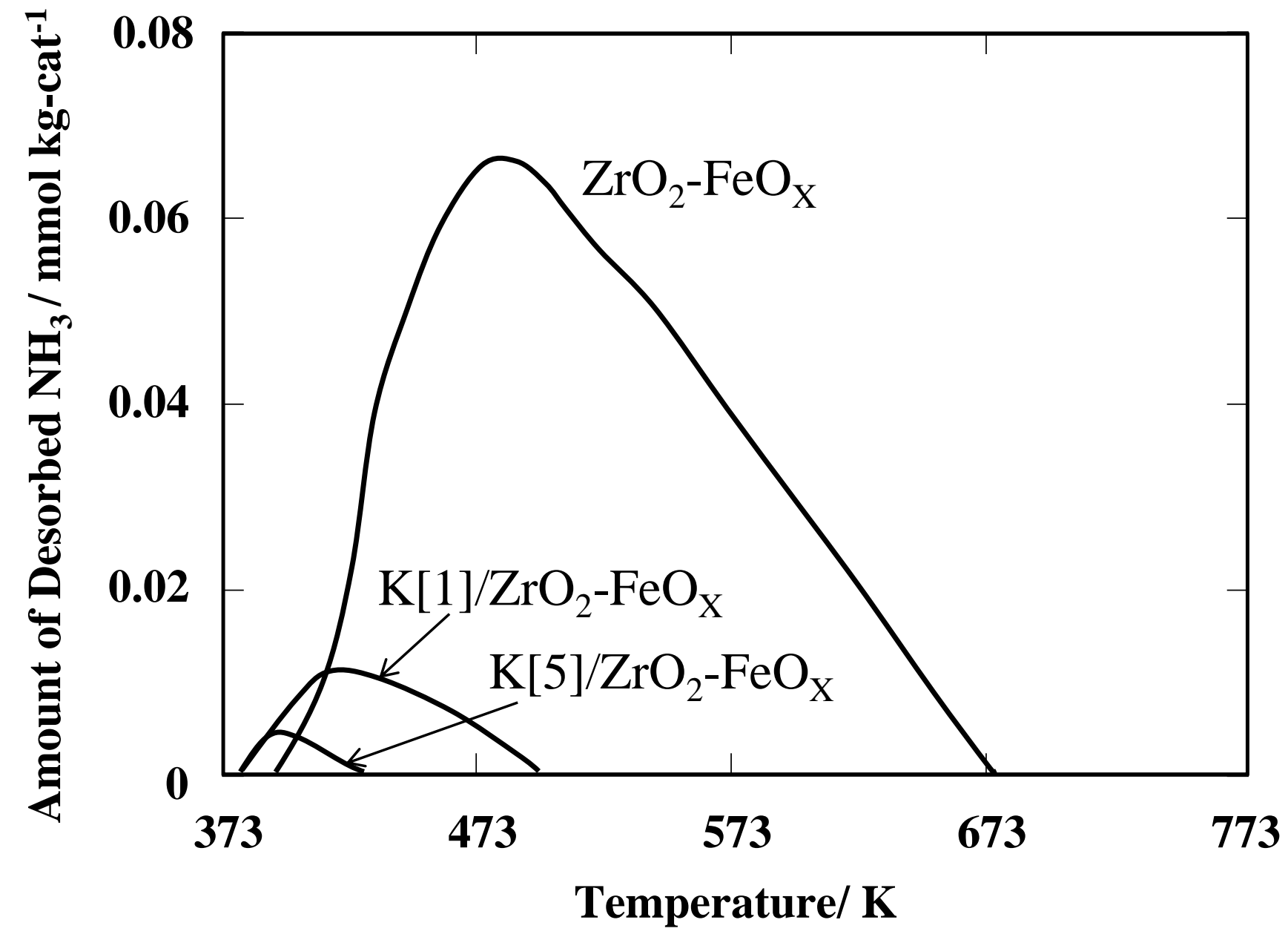

Figure 3. $\mathrm{NH}_{3}-\mathrm{TPD}$ profiles for $\mathrm{ZrO}_{2}-\mathrm{FeO}_{\mathrm{X}}, \mathrm{K}[1] / \mathrm{ZrO}_{2}-\mathrm{FeO} \mathrm{X}$, and $\mathrm{K}[5] / \mathrm{ZrO}_{2}-\mathrm{FeO}_{\mathrm{X}}$. 
(a)

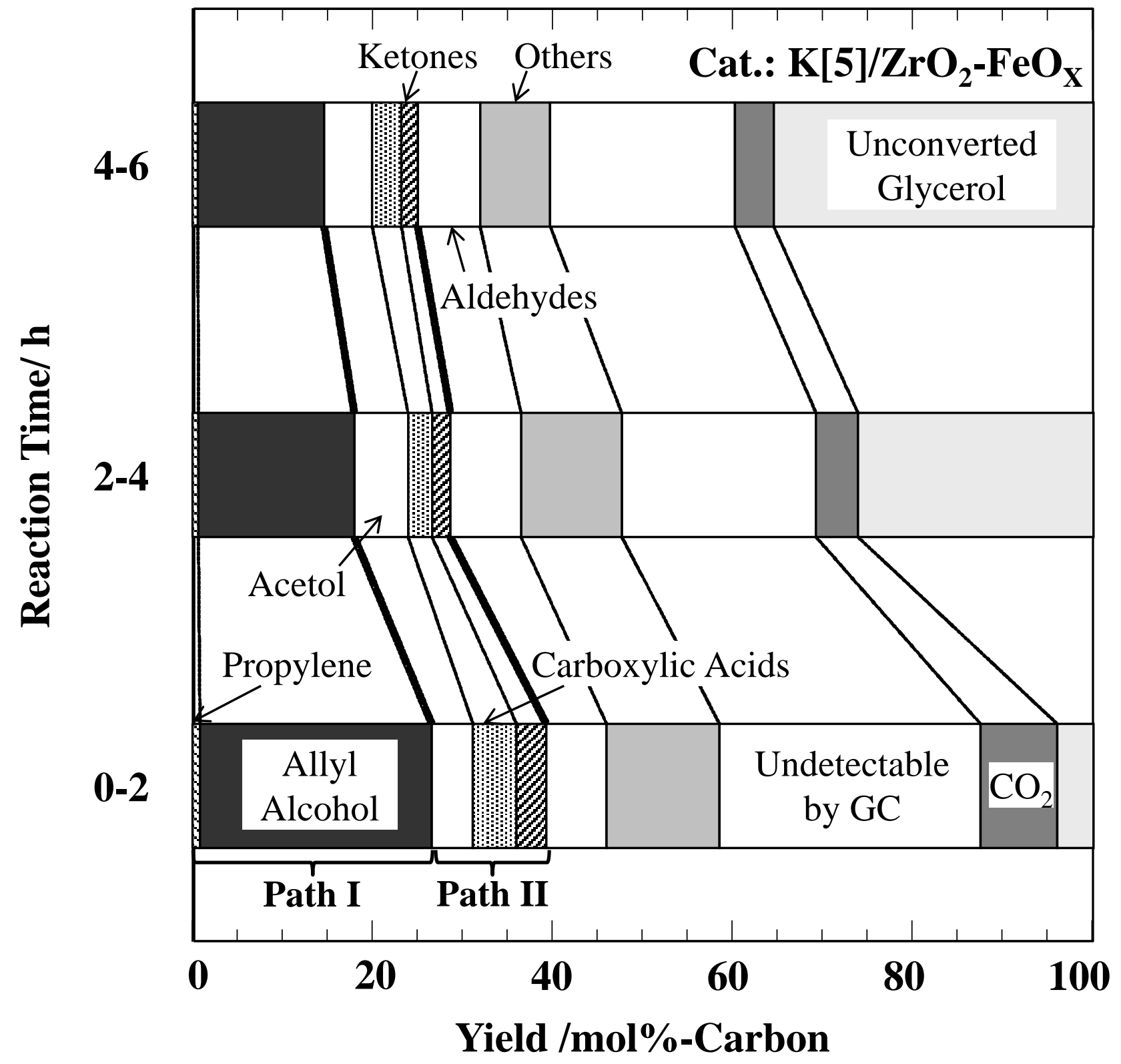

Figure 4(a). Stability of $\mathrm{K}[5] / \mathrm{ZrO}_{2}-\mathrm{FeO}_{\mathrm{X}}$.

Reaction conditions: $30 \mathrm{wt} \%$ glycerol solution, $\mathrm{K}[5] / \mathrm{ZrO}_{2}-\mathrm{FeO}_{\mathrm{X}}, W / F=1 \mathrm{~h}$, Reaction time $=6 \mathrm{~h}$. 


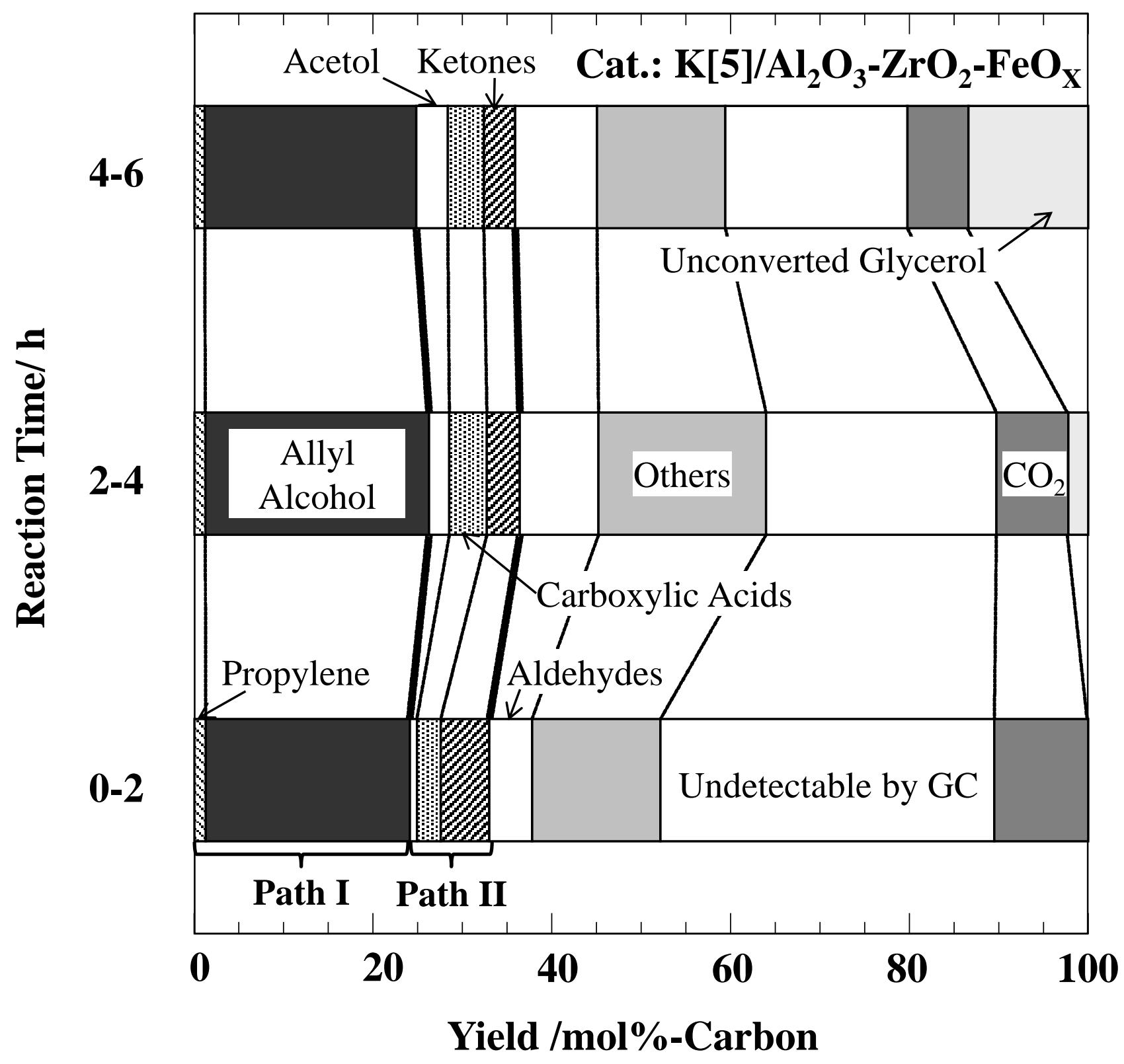

Figure 4(b). Stability of $\mathrm{K}[5] / \mathrm{Al}_{2} \mathrm{O}_{3}-\mathrm{ZrO}_{2}-\mathrm{FeO}_{\mathrm{X}}$.

Reaction conditions: $30 \mathrm{wt} \%$ glycerol solution, $\mathrm{K}[5] / \mathrm{Al}_{2} \mathrm{O}_{3}-\mathrm{ZrO}_{2}-\mathrm{FeO}_{\mathrm{X}}, W / F=3 \mathrm{~h}$, Reaction time $=6 \mathrm{~h}$. 


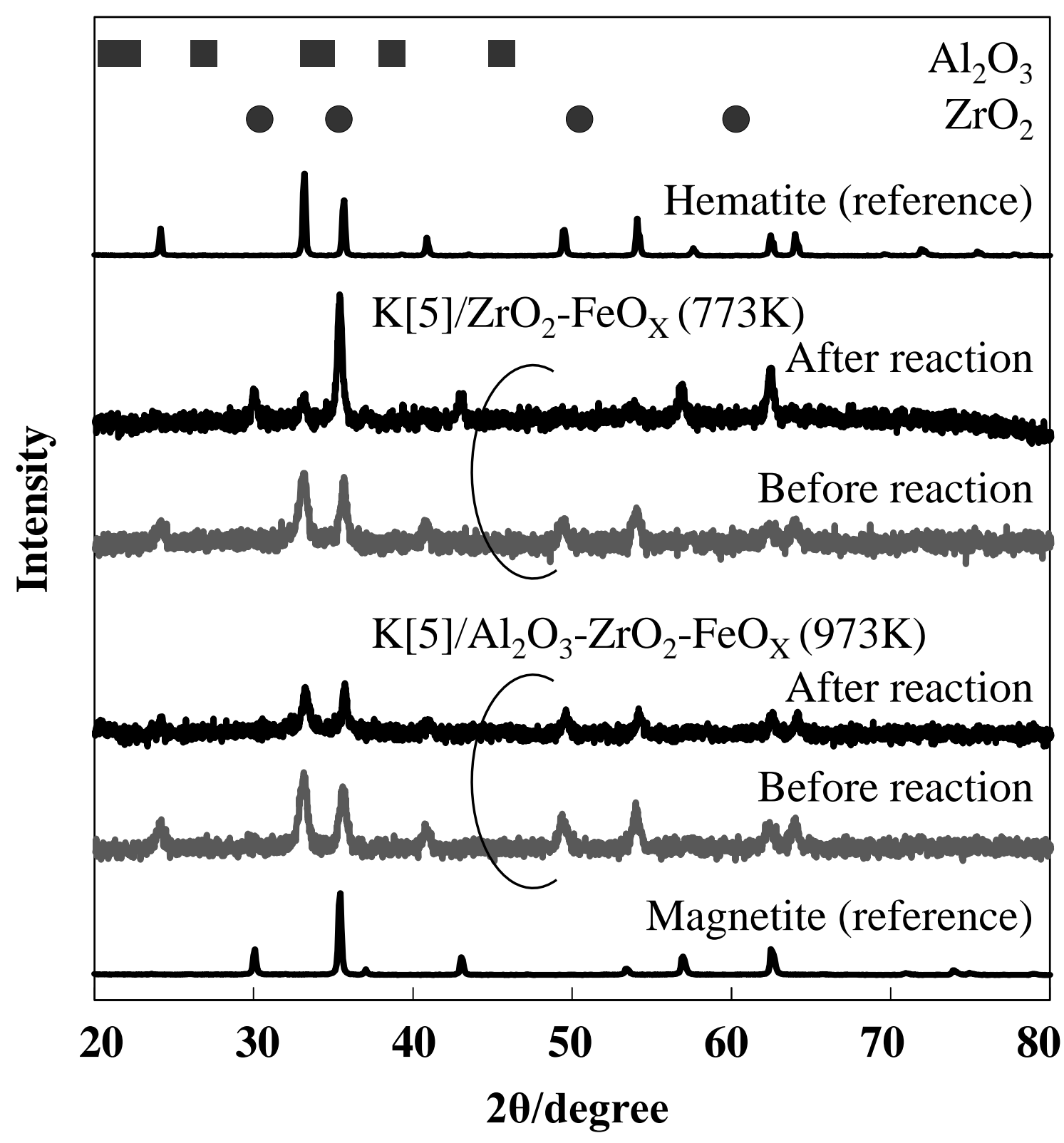

Figure 5. XRD patterns of $\mathrm{K}[5] / \mathrm{ZrO}_{2}-\mathrm{FeO}_{\mathrm{X}}$ and $\mathrm{K}[5] / \mathrm{Al}_{2} \mathrm{O}_{3}-\mathrm{ZrO}_{2}-\mathrm{FeO}_{\mathrm{X}}$ before and after the catalytic reaction. Reaction conditions: $30 \mathrm{wt} \%$ glycerol solution, $W / F=1 \mathrm{~h}$, Reaction time $=6 \mathrm{~h}$. 


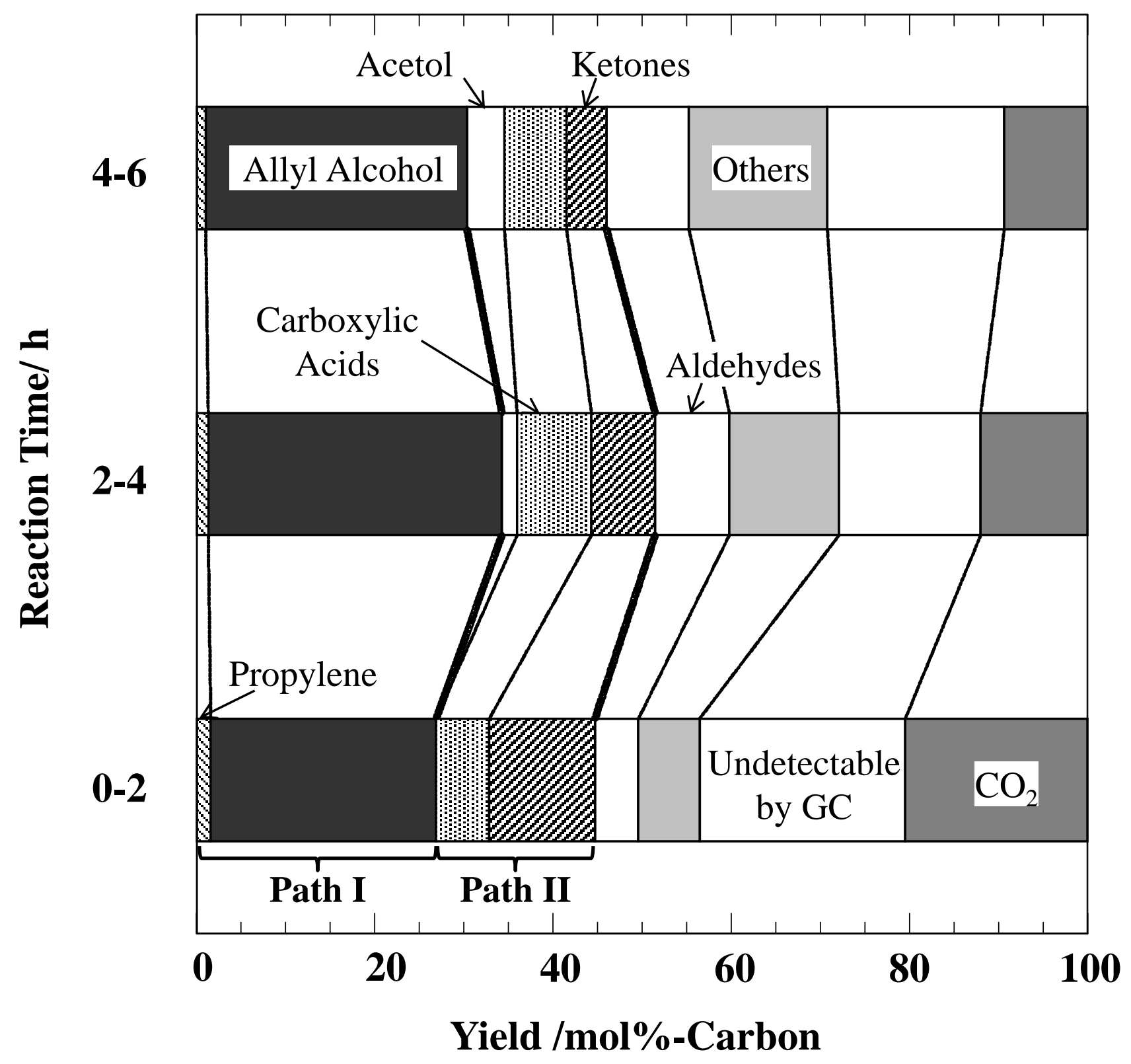

Figure 6. Catalytic conversion of crude glycerol using $\mathrm{K}[5] / \mathrm{Al}_{2} \mathrm{O}_{3}-\mathrm{ZrO}_{2}-\mathrm{FeO}_{\mathrm{X}}$. Reaction conditions: $10 \mathrm{wt} \%$ crude glycerol solution, $\mathrm{K}[5] / \mathrm{Al}_{2} \mathrm{O}_{3}-\mathrm{ZrO}_{2}-\mathrm{FeO}_{\mathrm{X}}, W / F=5 \mathrm{~h}$, Reaction time $=6 \mathrm{~h}$. 


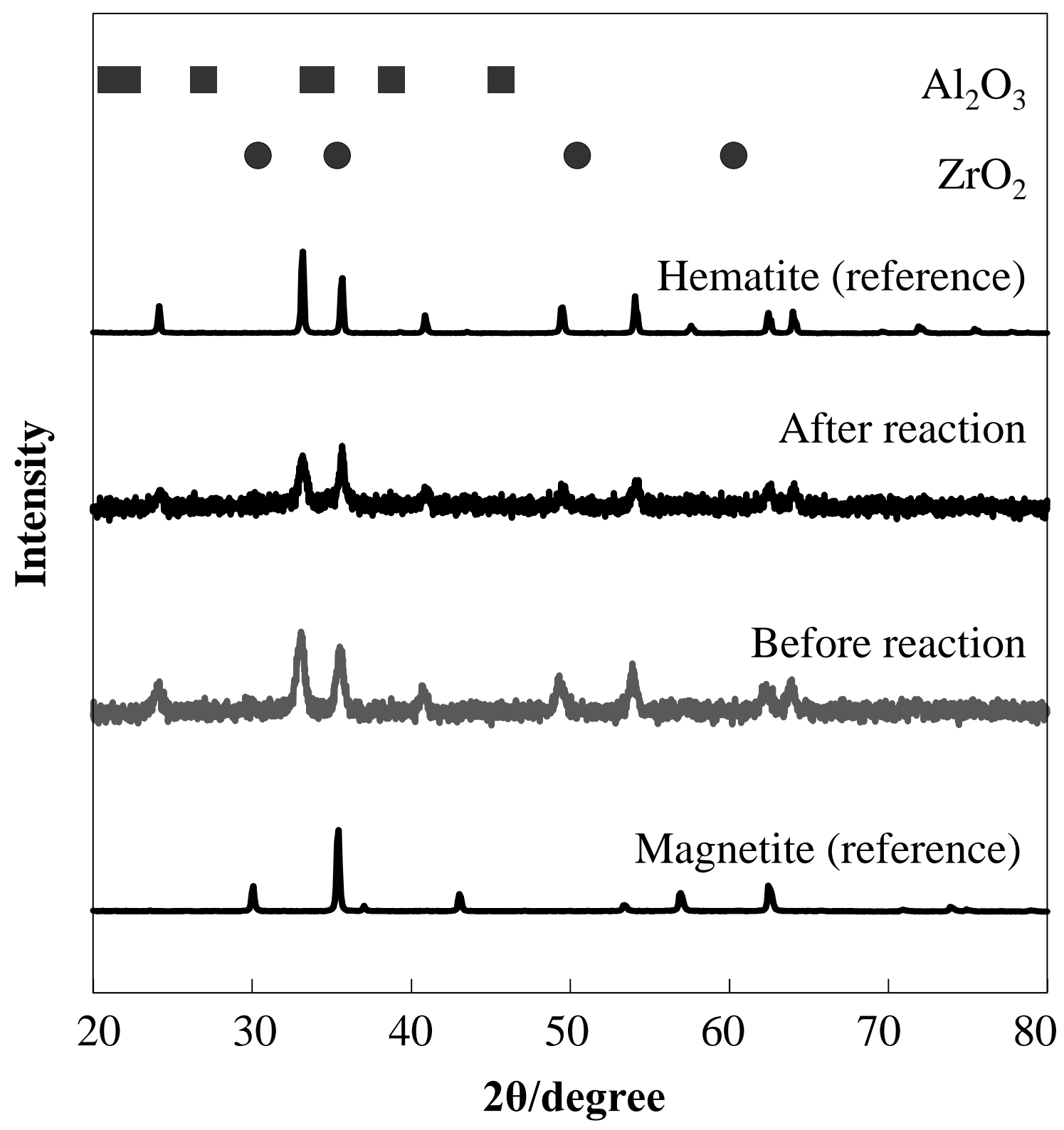

Figure 7. XRD patterns of $\mathrm{K}[5] / \mathrm{Al}_{2} \mathrm{O}_{3}-\mathrm{ZrO}_{2}-\mathrm{FeO}_{\mathrm{X}}$ before and after catalytic reaction of crude glycerol. Reaction conditions: $10 \mathrm{wt} \%$ crude glycerol solution, $W / F=5 \mathrm{~h}$, Reaction time $=6 \mathrm{~h}$. 